\title{
KANSAS CASE STUDY APPLICATIONS OF NITROGEN-15 NATURALABUNDANCE METHOD FOR IDENTIFICATION OF NITRATE SOURCES
}

\author{
${ }^{1}$ M. A. Townsend, ${ }^{1}$ D. P. Young, and ${ }^{2}$ S. A. Macko \\ ${ }^{1}$ Kansas Geological Survey, 1930 Constant Avenue, Lawrence, KS 66047; Phone: 785-864- \\ 3965; Fax: 785-864-5317; townsend@kgs.ku.edu; young@kgs.ku.edu. \\ ${ }^{2}$ University of Virginia, Department of Environmental Sciences, Charlottesville, VA 22903; \\ Phone: 434-924-6849; Fax: 434-982-2137; sam8f@virginia.edu.
}

\section{ABSTRACT}

The nitrogen-15 natural abundance method has been a tool for identifying sources of nitrate contamination in groundwater for almost 30 years. Different ranges of $\delta^{15} \mathrm{~N}$ in groundwater are associated with different sources such as fertilizer and animal wastes. However processes such as denitrification, nitrification, and volatilization can alter the $\delta^{15} \mathrm{~N}$ signature.

Use of this method in Kansas has had mixed results. One case study documented in this paper showed the utility of the method in an area with a sandy unsaturated zone and aquifer, a shallow water table, and an animal waste lagoon. The regional groundwater had an average nitrate-N concentration of $13 \mathrm{mg} / \mathrm{L}$ and a $\delta^{15} \mathrm{~N}$ signature of $+3 \%$, which indicates a fertilizer source. Effluent leaking from the lagoon $\left(\delta^{15} \mathrm{~N}\right.$ value of $+18 \%$ ) facilitated denitrification, affecting the regional groundwater, and resulted in a lower nitrate- $\mathrm{N}$ concentration of 4 $\mathrm{mg} / \mathrm{L}$ with a $\delta^{15} \mathrm{~N}$ signature of +12 to $+20 \%$ o downgradient of the site. The second case study illustrated the utility of the method to identify a variety of sources and the effects of the unsaturated zone on the observed $\delta^{15} \mathrm{~N}$ signature in areas with no observable animal waste sources. The presence of carbonate in a loess unsaturated zone resulted in enriched ${ }^{15} \mathrm{~N}$, owing to possible volatilization and preferential loss of ${ }^{14} \mathrm{~N}$.

Key words: nitrate, groundwater, nitrogen-15 isotope, sources, Kansas

\section{INTRODUCTION}

Nitrate is a common contaminant of groundwaters throughout the United States and the world. A survey of groundwater samples collected between 1990 and 1998 from municipal, irrigation, domestic, and monitoring wells in Kansas showed that $30 \%$ of the samples had nitrate-N (nitrate in this paper) concentrations $\leq 2 \mathrm{mg} / \mathrm{L} ; 50 \%$ had nitrate concentrations between 2 and 10 mg/L; and 20\% had values $\geq 10 \mathrm{mg} / \mathrm{L}$ (Townsend and Young, 2000; Townsend et al., 2001).

Nitrate concentrations greater than $2 \mathrm{mg} / \mathrm{L}$ in groundwater indicate possible anthropogenic sources (Mueller and Helsel, 1996). The National Primary Drinking Water Standard for nitrate is $10 \mathrm{mg} / \mathrm{L}$ (U.S. EPA, 2002).

Agriculture is the predominant industry in Kansas. Irrigated agriculture is the primary consumer of water and a source of agricultural chemicals, including nitrogen fertilizers (Figure 1). Potential non-point sources of nitrate-contaminated groundwater include soil nitrogen, fertilizer, and 


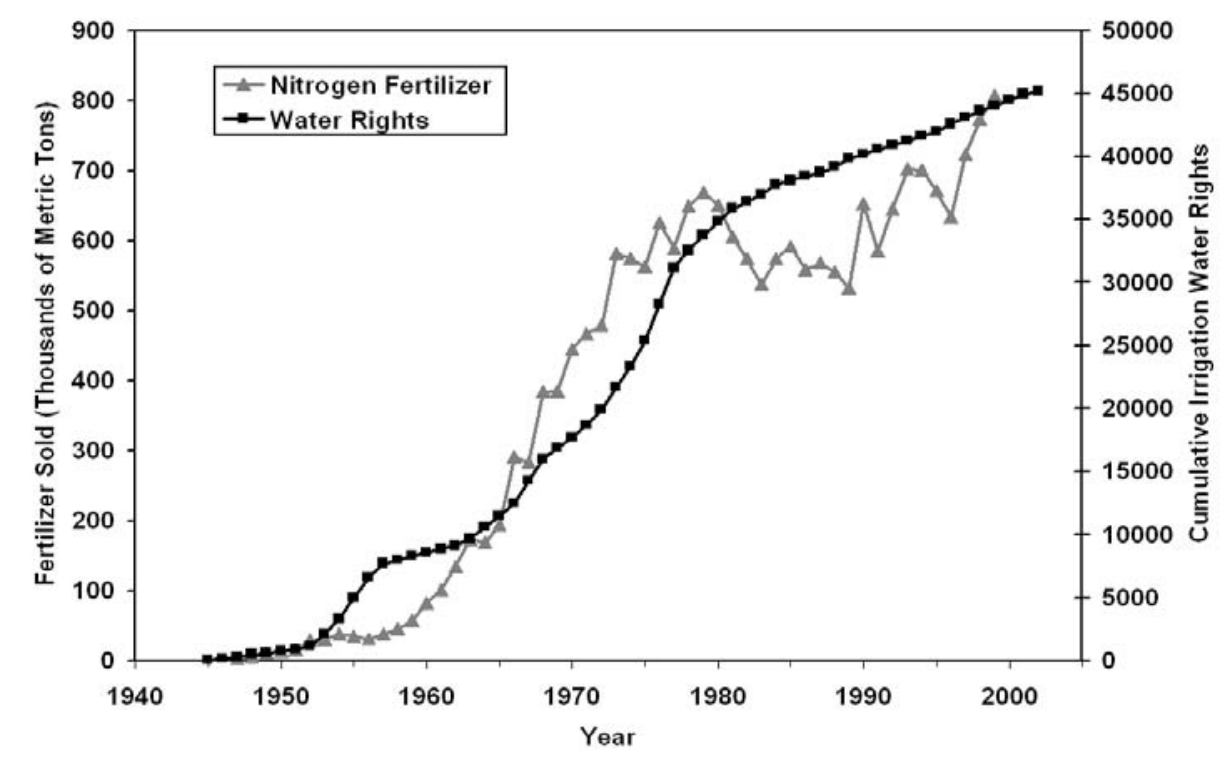

Figure 1. Nitrogen fertilizer sold and cumulative irrigation water rights issued in Kansas, 1945 to 2001. Data are from Kansas Department of Agriculture (2002) and Wilson (1998).

animal waste. Point sources include leaky septic systems, spills or leaks, container disposal sites, fertilizer cooperatives, and animal waste storage areas.

Identifying sources of nitrate in groundwater is an important step toward correcting the problem. Measurements of ${ }^{15} \mathrm{~N}$ abundances have been used for over 30 years to identify both point and non-point sources of nitrate. Work by Kreitler (1975, 1979), Kreitler and Jones (1975), Shearer et al. (1978), Kohl et al. (1971), Heaton (1986), Mariotti et al. (1988), Korom (1992), and Kendall (1998), and others, has contributed to development and use of the method. Examples of a few studies that illustrate the usefulness of the method include Gormly and Spalding (1979) in Nebraska, Mariotti et al. (1988) in France, Mitchell et al. (2003) in Canada, and Townsend et al. (1994) in Kansas.

\section{OBJECTIVES}

The purpose of this paper is to present the results of two case studies using ${ }^{15} \mathrm{~N}$ natural abundances to illustrate the utility and potential problems of the method in two areas in Kansas with different hydrogeology and land use. 


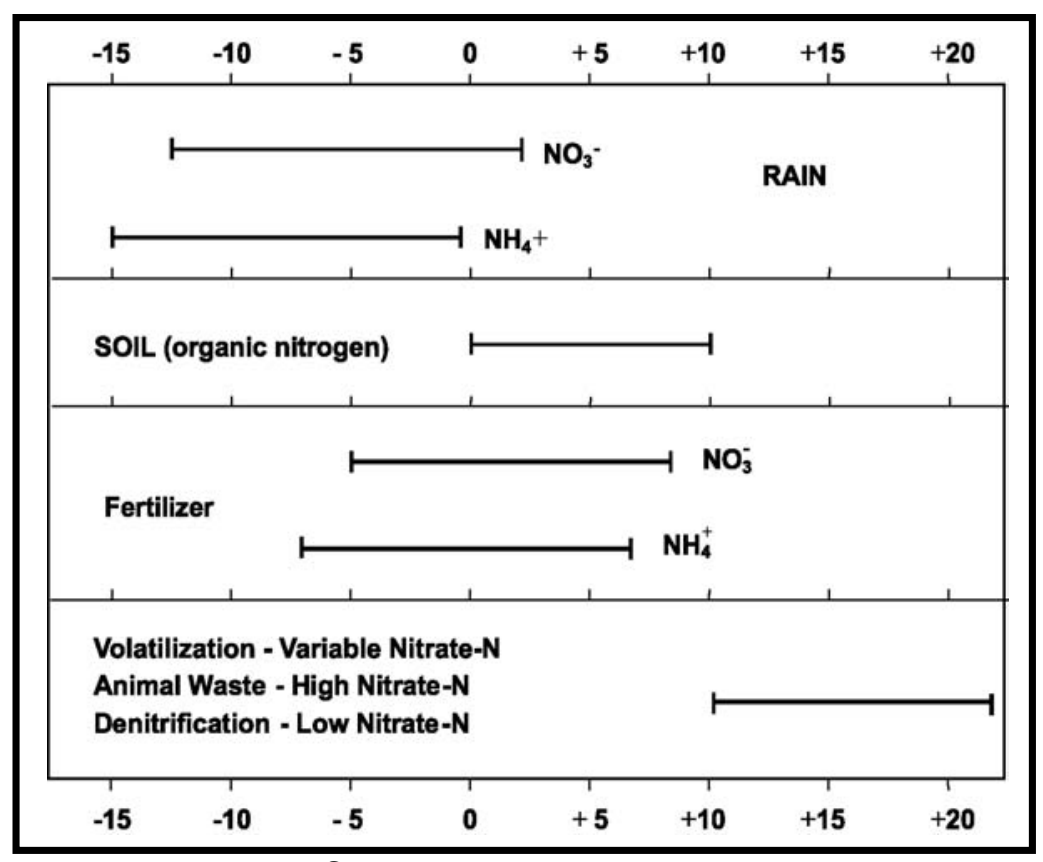

Figure 2. Range of $\delta^{15} \mathrm{~N}$ values associated with identified sources of groundwater nitrate and enrichment processes. Data are from a previous compilation (Heaton, 1986) and studies in Kansas (Townsend et al., 1994; Townsend, 2001) and Nebraska (Gormley and Spalding, 1979; Herbel and Spalding, 1993; Macko and Ostrom, 1994).

\section{BACKGROUND ON NITROGEN-15 NATURALABUNDANCE ISOTOPE TECHNIQUE}

Natural abundance nitrogen isotope analysis is a frequently used method to assist in determining sources of nitrogen in groundwater. The isotope analysis involves establishing the ratio of nitrogen-15 $\left({ }^{15} \mathrm{~N}\right)$ to nitrogen- $14\left({ }^{14} \mathrm{~N}\right)$ in nitrate in the sample of interest compared to the ratio observed in the standard, atmospheric nitrogen (air). Comparison of these ratios indicates if there is more (positive) or less (negative) ${ }^{15} \mathrm{~N}$ in the sample. The values thus indicate whether the sample is enriched (+) or depleted (-) in ${ }^{15} \mathrm{~N}$ with respect to a standard.

A range of groundwater $\delta^{15} \mathrm{~N}$ values is observed for various sources of nitrogen and associated enrichment processes (Figure 2; Heaton, 1986). Nitrogen from commercial fertilizers sources have $\delta^{15} \mathrm{~N}$ values from -7 to $+8 \%$, soil nitrogen has a range of +5 to $+7 \%$, and animal wastes are generally greater than $+10 \%$ (Kreitler, 1975; Heaton, 1986; Herbel and Spalding, 1993; Mayer et al., 2002).

Chemical reactions than can alter the $\delta^{15} \mathrm{~N}$ signature include nitrification, denitrification, and volatilization. Nitrification and denitrification are both biologically mediated. Generally, biological 
activities use ${ }^{14} \mathrm{~N}$ preferentially, resulting in an increased $\delta^{15} \mathrm{~N}$ value in the remaining nitrogen. Requirements for these reactions generally include the presence of the appropriate bacteria and an energy source for the bacteria to break the nitrogen bonds. Kendall (1998) presents the reactions for these processes.

Fertilizer sources have a wide range of values (Figure 2) because of the variety of source materials used to create the fertilizers. Acommon fertilizer used in Kansas is anhydrous ammonia, which is manufactured by the Haber process from air ( $\mathrm{N}$ source has $\delta^{15} \mathrm{~N}=0 \%$ ) plus natural gas reacted with steam. Ammonium-based fertilizers can be converted to nitrate through the bacterially mediated process of nitrification (Kendall, 1998). This reaction preferentially uses ${ }^{14} \mathrm{~N}$ resulting in an increase of ${ }^{15} \mathrm{~N}$ in the remaining nitrogen. Another mechanism for increasing ${ }^{15} \mathrm{~N}$ values is the volatilization of ammonia when ammonium-based fertilizers such as manure or anhydrous ammonia are applied (especially to calcareous soils). The resulting $\delta^{15} \mathrm{~N}$ values are frequently enriched to the +2 to $+8 \%$ range. Legume sources generally have much lower initial $\delta^{15} \mathrm{~N}$ signatures ( -2 to $+2 \%$ o) because their source nitrogen $\left(\mathrm{N}_{2}\right)$ has a $\delta^{15} \mathrm{~N}$ close to zero (as in air), and legumes use atmospheric nitrogen with little isotope fractionation (Kendall, 1998).

Other nitrogen sources such as human septic waste or animal waste have starting $\delta^{15} \mathrm{~N}$ values around $+5 \%$ (Kreitler, 1975). Because animal waste has a high ammonium-N component, the volatilization of ammonia gas causes the preferential loss of ${ }^{14} \mathrm{~N}$ with a resulting enrichment of ${ }^{15} \mathrm{~N}$ in the remaining nitrogen, which is converted to nitrate. Consequently, the $\delta^{15} \mathrm{~N}$ of the nitrate is $+10 \%$ or more.

Volatilization also can occur in soils and rocks with carbonate zones. Dissolution of soil carbonates can increase the $\mathrm{pH}$ of water towards 8.5 . In this range, nitrate can be converted to ammonia gas. The lighter ${ }^{14} \mathrm{~N}$ isotope is preferentially released in the gas. The remaining nitrogen becomes enriched in ${ }^{15} \mathrm{~N}$. This process most frequently occurs when fertilizer or manure is applied to calcareous soils. In addition, this process can occur at depths where the soil $\mathrm{pH}$ exceeds 8 (Herbel and Spalding, 1993). 
Another process that can result in a higher $\delta^{15} \mathrm{~N}$ value is denitrification. In this process, bacteria degrade nitrate to nitrogen gases that are released to the atmosphere. The ${ }^{14} \mathrm{~N}$ of the nitrate is preferentially utilized resulting in an enriched $\delta^{15} \mathrm{~N}$ in the remaining nitrate. Indicators of possible denitrification are low nitrate concentrations and enriched $\delta^{15} \mathrm{~N}$ values (Korom, 1992).

\section{METHODS}

Site characterization and evaluation of possible point sources near wells were accomplished using photographs, historical land-use information, crop histories, and fertilizer application rates; determining changes in irrigation practices; and locating old farmsteads, latrines, septic systems, barnyards, feedlots, manure storage sites, and disposal sites for agrichemical containers. Information on soil type, geology, and depth to groundwater; groundwater flow direction; historic water quality data; and location of surface water streams or lakes in the area were obtained from the National Resource Conservation Service (USDA, 2002) and USGS (2002), and the Kansas Geological Survey (KGS, 2002). Notes concerning land use around the well and farmstead were recorded to use in the evaluation of sources of nitrate in the water samples. Water samples and ${ }^{15} \mathrm{~N}$ samples were collected by KGS twice in the Reno County study and once in the Oberlin, Kansas, study.

Water samples were collected from wells after the well was purged for 3 to 5 well volumes and/or the temperature and specific conductance had stabilized for three consecutive readings at 3to 5-minute intervals. Unfiltered, unpreserved samples for cation analyses were collected in 500-ml polyethylene bottles. Unfiltered, unpreserved samples for anion analyses were collected in 250-ml

polyethylene bottles. Samples (200-ml volumes) for nitrate-N analysis were stored on ice in 250-ml polyethylene bottles with $2-\mathrm{ml} 6 \mathrm{M} \mathrm{HCl}$ as preservative. All samples were kept chilled on ice at $4{ }^{\circ} \mathrm{C}$ during fieldwork and transferred to a refrigerator upon return to KGS in Lawrence, Kansas. The KGS Analytical Services section determined nitrate concentrations within one month of sample time. Kansas Department of Health and Environment (KDHE) personnel from the confined animal feeding operations section assisted in collecting samples in Reno County, and the KDHE laboratory determined complete analyses on lagoon and well samples. The Kansas Department of Agriculture (KDA) chemigation program assisted in sampling of irrigation wells at both study sites. 
Water samples were routinely vacuum filtered using $0.45 \mu$ ash-free filter paper. Major inorganic analyses for calcium, magnesium, sodium, potassium, chloride, bicarbonate, carbonate, sulfate, and ammonium, iron, and manganese were done by the KGS Analytical Services Section by standard methods described in previous work (Hathaway et al., 1981). Nitrate analyses were done using a UV method for the Technicon Auto Analyzer II developed at the KGS (Hathaway, 1990). Specific conductance and $\mathrm{pH}$ were also done in the laboratory. The reproducibility (precision) of standards and controls was held to within $2 \%$. Accuracy of the chemical charge balance was held to within $2.0 \%$ or better at about 12 meq or more of total cations plus anions. Results for complete analyses are given in Townsend (2000, 2001). Partial analyses for specific constituents discussed in this paper are presented.

Samples for ${ }^{15} \mathrm{~N}$ analyses were collected in unpreserved 100 -ml volume polyethylene bottles and stored on ice at $4^{\circ} \mathrm{C}$ during field work. Samples were stored in the freezer until sent for analysis, usually within a two-week period from collection.

For total nitrogen, the samples are acidified to remove carbonate and dried. The carbonatefree residues were weighed into tin capsules and converted to $\mathrm{N}_{2}$ for isotope analysis using a Carlo Erba elemental analyzer (EA) which is coupled to an OPTIMA stable isotope ratio mass spectrometer (GVI, Manchester, UK). Nitrogen isotope content is determined with a single combustion using a dual-furnace system composed of an oxidation furnace at $1020^{\circ} \mathrm{C}$ and a reduction furnace at $650^{\circ} \mathrm{C}$. The resulting gases are chemically dried and directly injected into the source of the mass spectrometer. The standard for nitrogen is atmospheric $\mathrm{N}_{2}$ (air), which is assigned a value of $0.0 \%$. The reproducibility of the measurement is typically better than $\pm 0.2 \%$ o using the continuous-flow interface on the OPTIMA. In the laboratory, the samples are commonly measured against tanks of nitrogen gas, which have been calibrated against atmospheric $\mathrm{N}_{2}$.

Isotopic ratios are reported as $\delta^{15} \mathrm{~N}$ (delta nitrogen-15) in units of per mil (\%o) (Hoefs, 2001):

$$
\delta_{\text {sample }}(\% o)=\left[\left(\mathrm{R}_{\text {sample }}-\mathrm{R}_{\text {standard }}\right) / \mathrm{R}_{\text {standard }}\right] * 1000
$$

where $R$ is the ratio of ${ }^{15} \mathrm{~N} /{ }^{14} \mathrm{~N}$ of the sample and the standard, respectively. 


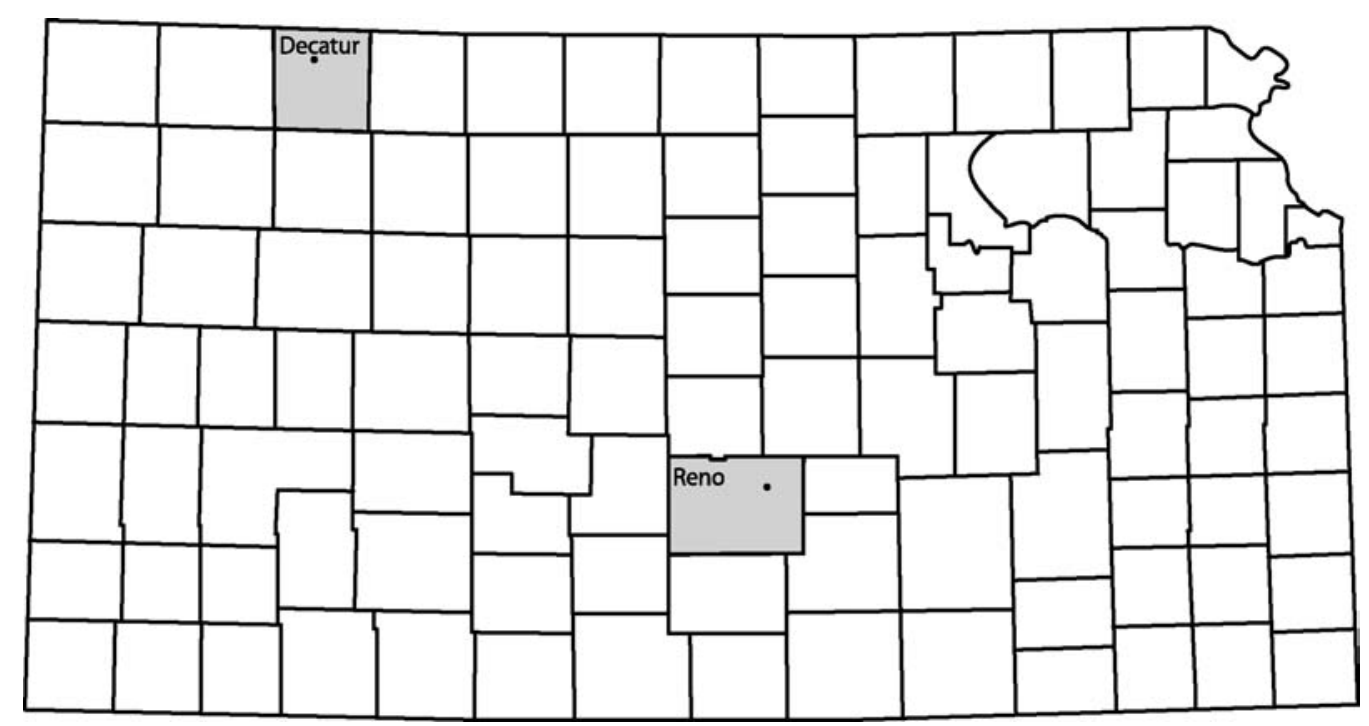

Figure 3. Location of two study sites in Kansas. Reno County is the site of a hog facility in south central Kansas. The city of Oberlin, Kansas, is located in Decatur County in northwestern Kansas.

\section{CASE STUDIES}

Two case studies are presented in this paper: one from Reno County and one from Decatur County (Figure 3). These two counties are of contrasting geology and general land use. The site in Reno County is a hog facility surrounded by dry land and irrigated farming. The municipal wells in Decatur County are surrounded by a variety of land uses including dry land and irrigated farming, calf feeder pens, sewage treatment areas, and a golf course.

\section{SITE CHARACTERIZATION}

\section{Reno County Hog Facility}

The study in Reno County in south central Kansas (Figure 3) was done in conjunction with the Kansas Department of Health and Environment (KDHE) and the local groundwater management district to determine if a local hog facility was the major contributor to the high nitrate concentration observed in the area. The hog facility in Reno County is situated in an area where sandy soil and a thin unsaturated zone overlie the sand and gravel Quaternary High Plains Aquifer. Shellabarger loam soil dominates the area and consists of an average sand content of 78\%, silt 9\%, and clay $12 \%$ (USDA (NRCS), 2002). The minimal amount of clay observed in the soil description indicates a very permeable soil and unsaturated zone. 


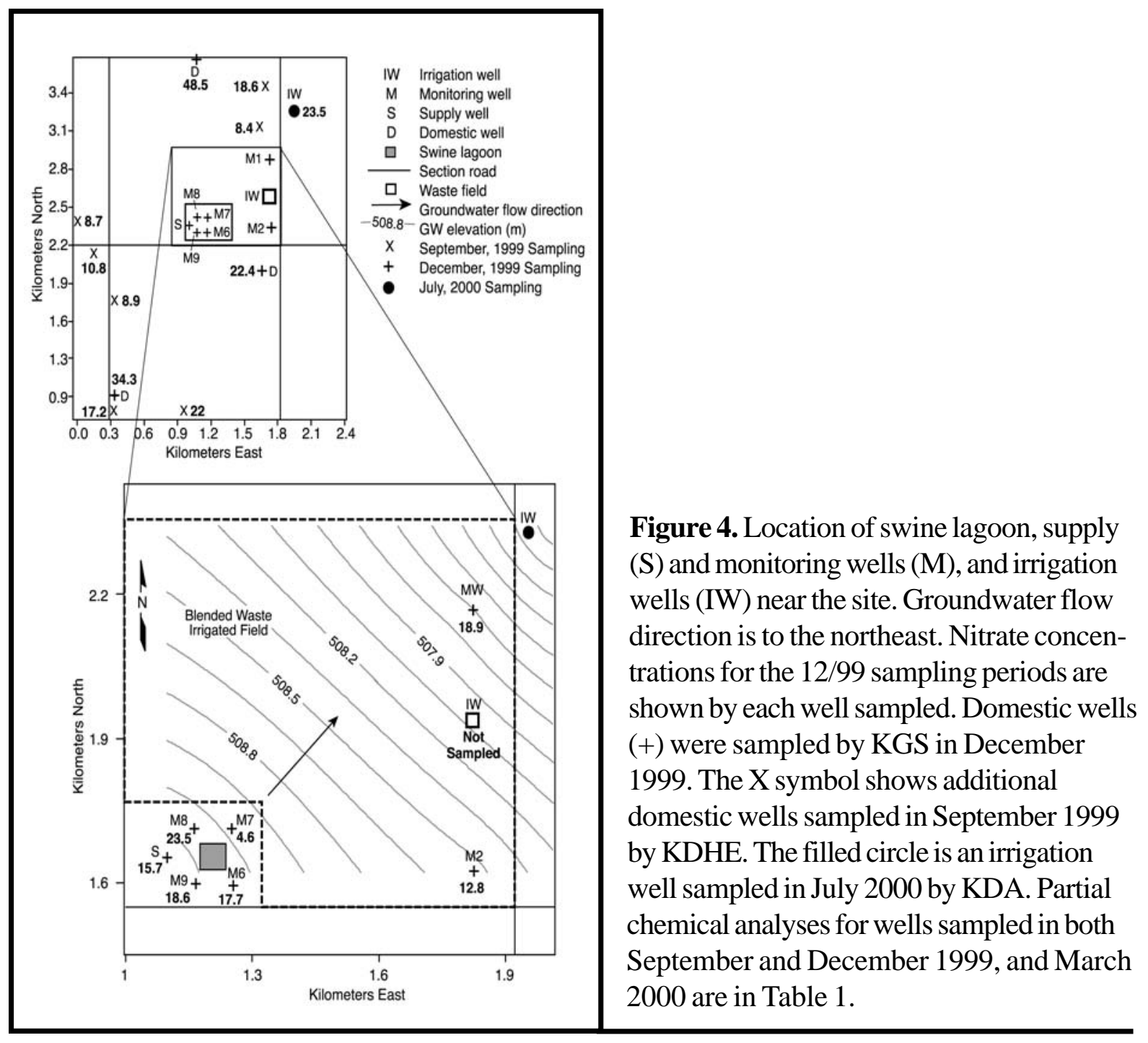

Depth to groundwater is $3.5 \mathrm{~m}(10 \mathrm{ft})$ and depth to bedrock is approximately $10.6 \mathrm{~m} \mathrm{(35}$

ft) (Bayne, 1956). Figure 4 shows the location of the swine lagoon, the monitoring and facility supply wells, site irrigation well, and adjacent irrigation well to the northeast of the spray field. Also shown are groundwater table contours in meters above sea level, December 1999 nitrate values, and locations of additional domestic wells sampled in September 1999 by KDHE. Partial chemical analyses for September and December 1999 and March 2000 are in Table 1 (Results section).

The lagoon is approximately $9,000 \mathrm{~m}^{2}\left(96,000 \mathrm{ft}^{2}\right)$ in surface area by $1.2 \mathrm{~m}(4 \mathrm{ft})$ deep with a $0.6-\mathrm{m}$ ( $2 \mathrm{ft}$ ) thick bentonite liner (Townsend, 2000). Measured leakage from the lagoon is $0.0794 \mathrm{~cm} /$ day (0.03125 in./day; Ham et al., 2000) or $7.1 \mathrm{~m}^{3} /$ day over the area of the lagoon (Townsend, 2001). Figure 5 shows the precipitation for the period of study (approximately 


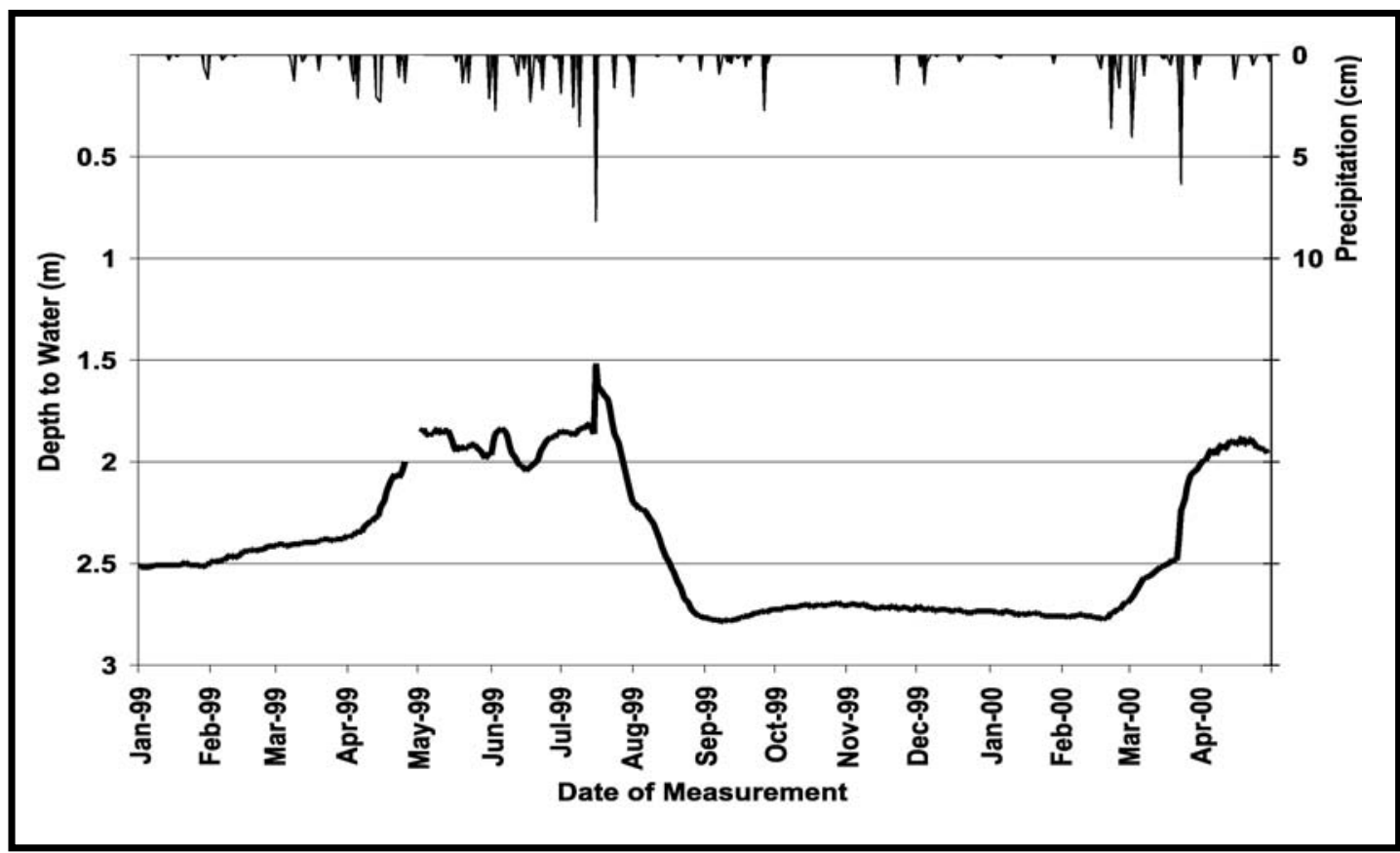

Figure 5. Groundwater table shows rapid response to precipitation events (Townsend, 2000).

$76 \mathrm{~cm} / \mathrm{yr} ; 30 \mathrm{in.} / \mathrm{yr}$ ) and the rapid response of the shallow water table because of the very permeable unsaturated zone.

The vertical cross sectional area of the sand and gravel aquifer in the direction of groundwater flow under the lagoon is approximately $1180 \mathrm{~m}^{2}\left(12,700 \mathrm{ft}^{2}\right)$. The estimated hydraulic conductivity value ranges from $6.3 \mathrm{~m} /$ day (20.8 ft/day) (Bayne, 1956) to $7.9 \mathrm{~m} /$ day ( $26 \mathrm{ft} /$ day) (Ham et al., 2000). The hydraulic gradient is estimated at $2.4 \mathrm{~m} / \mathrm{km}(12.6 \mathrm{ft} / \mathrm{mi})$ [(Kansas Groundwater Management District (GMD)] 2 staff, personal communication, 2000) to the northeast. Flow through the aquifer under the area of the lagoon is estimated at $17.8 \mathrm{~m}^{3} /$ day $\left(627 \mathrm{ft}^{3} /\right.$ day $)$.

\section{City of Oberlin, Kansas}

The city of Oberlin is located in Decatur County in northwestern Kansas (Figure 3). The city requested a study of possible sources of nitrate in the area because of historically high nitrate at several city wells and the observation of increasing nitrate at another city well (Townsend, 2001).

Land use in the area is a mix of irrigated and dry land farming with rangeland and feedlots also present. Figure 6 shows the sampling points and associated land use. Sappa Creek is the main surface drainage through the area. The shallow alluvial groundwater system is not connected to deeper regional groundwater in the High Plains aquifer. Groundwater flow is to the north-northeast. 


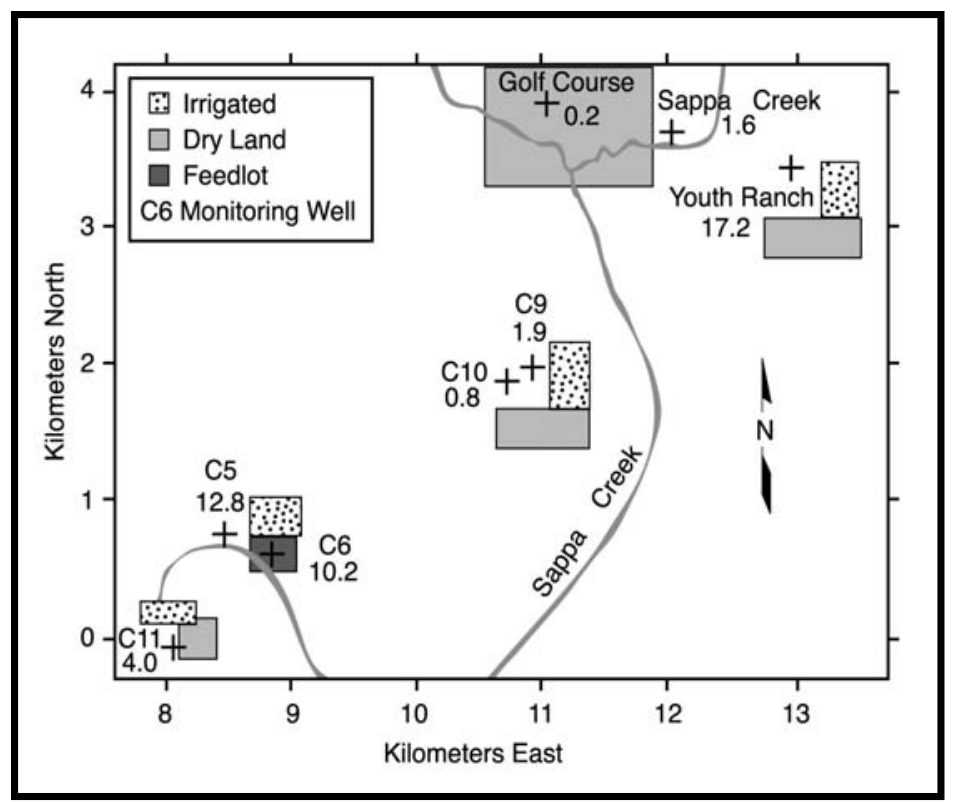

Figure 6. Site map of Oberlin city wells (C), golf course well, and youth ranch well with associated land use. Sampling points indicated by + . Nitrate values given for the well samples. Regional groundwater flow is to the north-northeast.

Due to groundwater pumping in the area, groundwater no longer supplies water to most of Sappa Creek. U.S. Geological Survey stream-flow records for Sappa Creek indicate little flow in the creek after the mid-1980s (USGS, 2002).

The geology of the area consists of alluvial sediments and the overlying Pleistocene loess deposits and the Ogallala Formation in the upland areas. In the vicinity of Oberlin, the wells are sited in the alluvial sediments of Sappa Creek. The wells range in depth from 15 to $24 \mathrm{~m}$ (50 to 80 feet) deep.

Soils in the area are generally alluvial in origin and consist of the Bridgeport silt loam or Holdrege silt loam soils. The Bridgeport series consists of deep, well-drained, moderately permeable soils on stream terraces and alluvial fans and is formed in calcareous, silty alluvium (Hamilton et al., 1989; USDA (NRCS), 2002). The Holdrege series consists of deep, well-drained, moderately permeable soils on uplands and is formed in loess.

The soils are predominantly silt-size with variable amounts of sand and clay. Permeability is low to moderate ( 1.5 to $5 \mathrm{~cm} / \mathrm{hr}, 0.6$ to $2 \mathrm{in} / \mathrm{hr}$ ). Field descriptions of these soils show a strong calcareous component, as indicated by moderate to violent effervescence (J. McDowell, 2000, personal communication). The soil water chemistry changes with depth and becomes more basic. 


\section{RESULTS}

\section{Water Chemistry Reno County Hog Facility}

Regionally, groundwater surrounding the hog facility in Reno County is calcium-

bicarboate type water with low chloride concentrations (generally less than $15 \mathrm{mg} / \mathrm{L}$ ) and high

Table 1. Partial chemical analyses from wells in Reno County.

\begin{tabular}{|c|c|c|c|c|c|c|c|c|c|c|}
\hline $\begin{array}{l}\text { Sample Id } \\
\text { Reno Cty. }\end{array}$ & Date & $\begin{array}{c}\delta^{15} \mathbf{N} \\
\% o\end{array}$ & $\begin{array}{c}\text { SPCD* }^{*} \\
\mu \mathrm{mhos} / \mathrm{cm}\end{array}$ & $\begin{array}{c}\text { Calc } \\
\text { TDS }^{* *}\end{array}$ & $\begin{array}{c}\mathrm{HCO}_{3} \\
\mathrm{ppm}\end{array}$ & $\begin{array}{l}\mathrm{SO}_{4} \\
\mathrm{ppm}\end{array}$ & $\begin{array}{c}\text { CI } \\
\text { ppm }\end{array}$ & $\begin{array}{c}\mathrm{NO}_{3}-\mathrm{N} \\
\text { ppm }\end{array}$ & $\begin{array}{c}\mathrm{NH}_{4}-\mathrm{N} \\
\text { ppm }\end{array}$ & $\begin{array}{c}\text { Depth } \\
\text { m }\end{array}$ \\
\hline Supply & Sept-99 & & & 97 & 58 & 13.4 & 9.2 & 13.5 & & 10.4 \\
\hline Supply & Dec-99 & 7.8 & 280 & 189 & 59 & 14.8 & 3.8 & 15.7 & & \\
\hline Supply & Mar-00 & 1.2 & 264 & 158 & 58 & 12.8 & 5.3 & 14.6 & & \\
\hline M6 & Sept-99 & & & 105 & 52 & 13.8 & 8.9 & 21.2 & & 4.9 \\
\hline M6 & Dec-99 & 5.9 & 263 & 193 & 56 & 11.5 & 3.0 & 17.7 & & \\
\hline M6 & Mar-00 & 0.8 & 321 & 194 & 54 & 11.9 & 4.3 & 22.5 & & \\
\hline M7 & Sept-99 & & & 246 & $\overline{189}$ & 15.6 & 70.9 & 10.4 & & 4.9 \\
\hline M7 & Dec-99 & 20.8 & 1060 & 728 & 437 & 16.3 & 159 & 4.6 & & \\
\hline M7 & Mar-00 & 12.8 & 1205 & 645 & 486 & 14.4 & 133.6 & 5.8 & & \\
\hline M8 & Sept-99 & & & 169 & 79 & 12.4 & 7.6 & 28.5 & & 5.2 \\
\hline M8 & Dec-99 & 9.6 & 350 & 258 & 84 & 12.9 & 2.1 & 23.5 & & \\
\hline M8 & Mar-00 & 1.6 & 610 & 353 & 59 & 8 & 5.4 & 49.4 & & \\
\hline M9 & Sept-99 & & & 97 & 58 & 12 & 6.7 & 16.3 & & 5.2 \\
\hline M9 & Dec-99 & 5.7 & 264 & 198 & 59 & 9.7 & 1.9 & 18.6 & & \\
\hline M9 & Mar-00 & 2.6 & 290 & 180 & 74 & 8.3 & 2.8 & 19.2 & & \\
\hline M1 & Jul-96 & & 260 & 185 & 78 & 16.3 & 3.3 & 14.5 & & 10.4 \\
\hline M1 & Dec-99 & 6.8 & 364 & 249 & 108 & 15.3 & 4.0 & 18.9 & & \\
\hline M2 & Jul-96 & & 270 & 195 & 82 & 17.3 & 3.7 & 15.7 & & 10.4 \\
\hline $\mathrm{M} 2$ & Dec-99 & 8.8 & 342 & 226 & 112 & 20.2 & 3.6 & 12.8 & & \\
\hline Lagoon & Jul-96 & & 5400 & 3469 & 4392 & 50 & 288 & 0.5 & 450 & \\
\hline Lagoon & Dec-99 & 18.2 & & 5604 & 3926 & 23.9 & 547 & 0.3 & 1484 & \\
\hline IW at site & Jul-96 & & 277 & & 66 & 17.8 & 5.2 & 18.9 & & 10.4 \\
\hline $\begin{array}{c}\text { IW NE of } \\
\text { facility }\end{array}$ & Jul-00 & 5.8 & 378 & & 84 & 16.5 & 5.8 & 23.5 & & \\
\hline \multirow[t]{2}{*}{ R.H. Dom } & Sept-99 & & & 310 & 200 & 52.0 & 20.4 & 31.6 & & \\
\hline & Dec-99 & 11.3 & 735 & 468 & 201 & 55.2 & 16.9 & 34.3 & & \\
\hline \multirow[t]{2}{*}{ J.S. Dom } & Sept-99 & & & 402 & 342 & 19.2 & 23.5 & 41.1 & & \\
\hline & Dec-99 & 11.6 & 975 & 619 & 338 & 18.1 & 22.8 & 48.5 & & \\
\hline \multirow[t]{2}{*}{ M.H. Dom } & Sept-99 & & & 215 & 138 & 32.3 & 19.0 & 20.5 & & \\
\hline & Dec-99 & 10.2 & 491 & 304 & 131 & 32.5 & 13.7 & 22.4 & & \\
\hline J. H. Dom & Sept-99 & & & 200 & 133 & 34 & 13 & 18.6 & & \\
\hline A. U. Dom & Sept-99 & & & 266 & 219 & 28 & 16.4 & 17.2 & & \\
\hline A. M. Dom & Sept-99 & & & 327 & 195 & 53.4 & 41.7 & 22 & & \\
\hline P. H. Dom & Sept-99 & & & 150 & 115 & 22 & 8.1 & 8.9 & & \\
\hline G. R. Dom & Sept-99 & & & 456 & 202 & 147 & 46.5 & 8.7 & & \\
\hline G. Y. Dom & Sept-99 & & & 306 & 143 & 48 & 17.6 & 10.8 & & \\
\hline S. C. Dom & Sept-99 & & & 111 & 86 & 14 & 7 & 8.4 & & \\
\hline
\end{tabular}

$\mathrm{SPCD}=$ Specific conductance $; *$ Calc TDS $=$ Calculated total dissolved solids; Dom = Domestic well; $\mathrm{M}=$ Monitoring well; IW= Irrigation well. 
nitrate concentrations (generally greater than $10 \mathrm{mg} / \mathrm{L}$; Table 1). Previous water sampling of domestic wells in the area surrounding the hog facility by the Kansas Department of Health and Environment (KDHE) showed an average nitrate concentration of $18 \mathrm{mg} / \mathrm{L}$ and a chloride concentration of $20 \mathrm{mg} / \mathrm{L}$ (Sept. 1999 samples Table 1). The chemistry of the supply and monitoring wells upgradient of the lagoon (Figure 4, wells M6, M8, and M9 and supply well for the December 1999 sampling period) all show high nitrate values (mean of $18.8 \mathrm{mg} / \mathrm{L}$ ) but low chloride (mean value of 3 $\mathrm{mg} / \mathrm{L}$ ). Well M7, downgradient of the lagoon (Figure 4), has a nitrate concentration of $4.6 \mathrm{mg} / \mathrm{L}$ and a chloride content of $159 \mathrm{mg} / \mathrm{L}$. The lagoon contains ammonium- $\mathrm{N}$ at a concentration of 1484 $\mathrm{mg} / \mathrm{L}$ and chloride of $547 \mathrm{mg} / \mathrm{L}$. The irrigation well to the east of the facility was sampled in July 2000 and showed nitrate at $23.5 \mathrm{mg} / \mathrm{L}$ and chloride at $5.8 \mathrm{mg} / \mathrm{L}$.

\section{Chloride as a Tracer}

Chloride is a conservative tracer, which means the concentrations are generally not impacted by biological or chemical processes. In addition, it has been observed that movement of negative ions such as chloride through clay liners can occur whereas positive ions such as ammonium will be retained in the clays due to adsorption onto them (Drever, 1982).

Chloride concentration for the regional groundwater showed a mean value of $3 \mathrm{mg} / \mathrm{L}$. The lagoon had a measured chloride of $547 \mathrm{mg} / \mathrm{L}$ and the well M7 downgradient of the lagoon (Fig. 4) had a chloride value of $159 \mathrm{mg} / \mathrm{L}$. Because of the low regional chloride value in the area (Table 1), it was assumed that the source of the well M7 chloride was from the lagoon.

The dilution model of Hem (1985) was used to determine if mixing and dilution were the sole cause of the observed chloride and nitrate values in well M7. The calculated chloride value at well M7 was $158 \mathrm{mg} / \mathrm{L}$ and the actual concentration was $159 \mathrm{mg} / \mathrm{L}$, indicating that dilution of the lagoon water by regional groundwater had occurred.

Using the dilution-mixing model for nitrate, the calculated value at well M7 was $12.9 \mathrm{mg} / \mathrm{L}$. The observed value was $4.6 \mathrm{mg} / \mathrm{L}$. The difference in these values suggests that dilution was not the sole process associated with the observed nitrate value. 


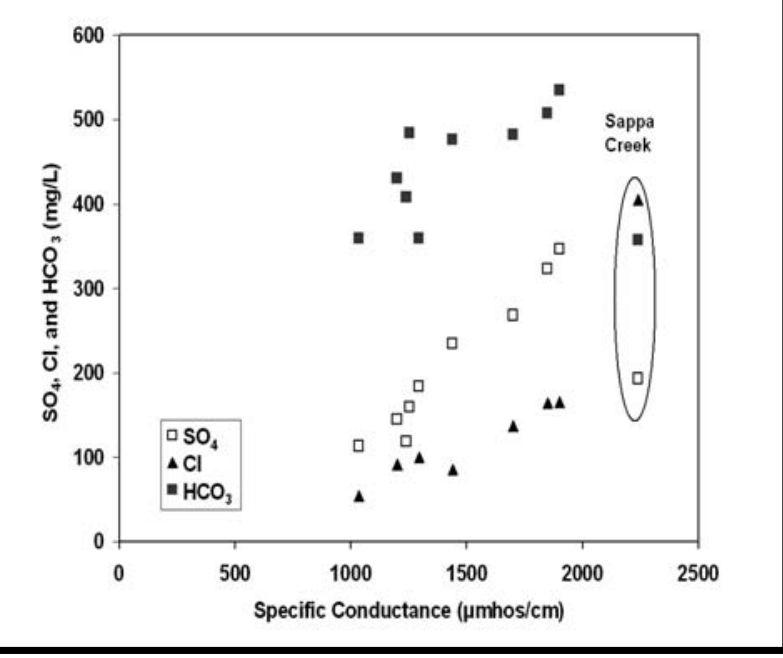

Figure 7. Concentration of sulfate, chloride, and bicarbonate versus specific conductance from sampled wells and Sappa Creek. Concentrations of chloride in Sappa Creek and high specific conductance suggest evapoconcentration of surface-water runoff.

\section{Water Chemistry in Oberlin Area}

The water in the Oberlin, Kansas, area is generally a calcium-bicarbonate-sulfate water type (Townsend, 2001). All the wells have specific conductance readings greater than $1000 \mu \mathrm{mhos} / \mathrm{cm}$ (Figure 7; Table 2). There is a direct relationship of chloride, sulfate, and bicarbonate with increasing specific conductance (Figure 7). This relationship suggests that evaporation and concentration of solutes, as well as dissolution of salts within the unsaturated zone, are responsible for the high concentrations at sites near dry land and irrigated farming (Whittemore, 1995; Townsend, 2001). The higher concentrations of salts make it difficult to use the anions of chloride and sulfate to assist in source identification for nitrate in this area.

The Sappa Creek sample also shows the influence of higher anion concentrations that may be a result of evaporation concentration of surface-water runoff or possible influence by treated sewage effluent (Townsend, 2001).

\section{DISCUSSION}

\section{Nitrogen-15 Results at Reno County Site}

The ${ }^{15} \mathrm{~N}$ natural abundances were used to determine if contamination in the area was from regional non-point sources, point sources, or more specifically, was from the swine facility lagoon 
contributing to high groundwater nitrate. Figure 4 shows the groundwater flow direction and nitrate values from the December 1999 sampling event at the site. The overall high concentrations surrounding the lagoon site suggest a long-term non-point source of contamination occurring upgradient of the site. The area surrounding the swine facility is generally dry land and irrigated agriculture. Rapid recharge of nitrified fertilizer was proposed as the primary source of contamination in the area. Movement of fertilizer from south and west of the lagoon (Figure 4) results in the high nitrate values observed at the supply and monitoring wells on the west and south sides of the lagoon (M8, supply well, M6, M9). Note the low nitrate value at well M7 (4.6 mg/L) on the northeast side of the lagoon, in the downgradient flow direction (Figure 4, Table 1). The irrigation well to the northeast of the hog facility (Table 1) had a nitrate concentration of $23.5 \mathrm{mg} / \mathrm{L}$, indicating further that the area around the facility had overall high nitrate.

Figure 8 is a diagram of $\delta^{15} \mathrm{~N}$ versus nitrate concentration, with zones indicating different probable sources of nitrate and enrichment processes that can affect $\delta^{15} \mathrm{~N}$ values. The fertilizer zone extends from $<0 \%$ o to $+8 \%$. The range is large because of the variety of fertilizer source materials as well the effects of isotope enrichment processes discussed previously.

The animal waste zone is generally defined as greater than $+10 \%$ o based on the work of Kreitler (1975). In Kansas, sites that have obvious animal waste sources typically have nitrate

Table 2. Partial waster chemistry analyses for city of Oberlin, Kansas, wells.

\begin{tabular}{|c|c|c|c|c|c|c|c|c|c|c|c|c|}
\hline $\begin{array}{l}\text { Sample Id } \\
\text { Oberlin, KS }\end{array}$ & Date & $\delta^{15} \mathbf{N} \% 0$ & $\begin{array}{l}\mu \mathrm{SPCD} * \\
\text { mhos/cm }\end{array}$ & $\begin{array}{c}\text { Calc } \\
\text { TDS** } \\
\text { ppm }\end{array}$ & $\begin{array}{l}\mathrm{CO}_{3} \\
\mathrm{ppm}\end{array}$ & $\begin{array}{c}\mathrm{HCO}_{3} \\
\mathrm{ppm}\end{array}$ & $\begin{array}{l}\mathrm{SO}_{4} \\
\mathrm{ppm}\end{array}$ & $\begin{array}{c}\mathrm{Cl} \\
\mathrm{ppm}\end{array}$ & $\begin{array}{c}\mathrm{NO}_{3}-\mathrm{N} \\
\mathrm{ppm}\end{array}$ & $\begin{array}{c}\mathrm{Fe} \\
\mathrm{ppm}\end{array}$ & $\begin{array}{l}\text { Mn } \\
\text { ppm }\end{array}$ & $\begin{array}{c}\text { Depth } \\
\text { m }\end{array}$ \\
\hline Sappa Ck & Mar-01 & 3.0 & 2240 & 1525 & 8.8 & 357 & 193 & 405 & 1.6 & & & \\
\hline C 5 & Mar-01 & 10.7 & 1035 & 789 & & 359 & 113 & 54.1 & 12.8 & & & 20.7 \\
\hline C 6 & Mar-01 & 14.7 & 1700 & 1277 & & 482 & 268 & 137 & 10.2 & & & 20.7 \\
\hline C 9 & Mar-01 & 12.5 & 1850 & 1381 & & 507 & 323 & 164 & 1.9 & & & 24.4 \\
\hline C 10 & Mar-01 & 3.8 & 1900 & 1467 & & 535 & 346 & 165 & 0.8 & & & 24.1 \\
\hline C 11 & Mar-01 & 13.2 & 1440 & 1044 & & 476 & 234 & 85.4 & 4.0 & & & 23.2 \\
\hline Golf Course & Mar-01 & 0.4 & 1200 & 882 & & 430 & 145 & 91.2 & 0.2 & 2.63 & 0.71 & 15.3 \\
\hline Youth Ranch & Mar-01 & 5.7 & 1295 & 888 & & 359 & 184 & 100 & 17.2 & & & 15.3 \\
\hline Rainfall*** & Feb-94 & -2.2 & & & & & & & 0.89 & & & \\
\hline
\end{tabular}

*SPCD = Specific conductance; $* *$ TDS = Total dissolved solids; ***Rainfall data from Schulmeister (1994); C = city well 


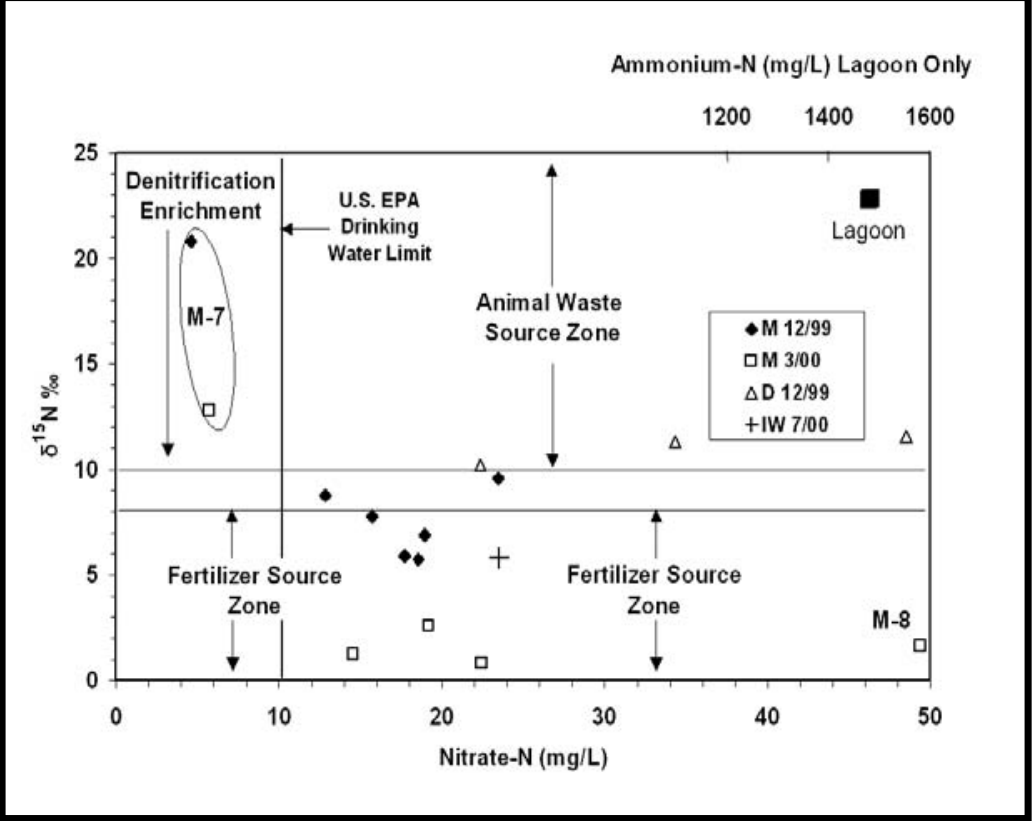

Figure 8. Diagram of $\delta^{15} \mathrm{~N}$ versus nitrate concentration with zones indicating probable sources of nitrate, and enrichment processes that can affect $\delta^{15} \mathrm{~N}$ values. Monitoring well M7 falls in area of graph separate from other monitoring wells because of mixing of waters and denitrification enrichment. Ammonium-N value for the lagoon sample is on the secondary X-axis. Mindicates monitoring wells, D for domestic wells, and IW for irrigation. Years of sampling are indicated by 99 (1999) and 00 (2000).

values greater than $10 \mathrm{mg} / \mathrm{L}$ (Townsend et al., 1994; Townsend, 2001). The denitrification zone generally has $\delta^{15} \mathrm{~N}$ values greater than $+10 \%$, but the nitrate concentrations are less than $1 \mathrm{mg} / \mathrm{L}$ and reducing water chemistry is observed.

Values of $\delta^{15} \mathrm{~N}$ for the samples plot in several zones of Figure 8. The domestic wells fall in the animal waste zone (nitrate $>10 \mathrm{mg} / \mathrm{L}$ and $\delta^{15} \mathrm{~N}$ values $>+10 \%$ ). All three domestic samples were affected by one or more of the following: (1) old, shallow-dug wells susceptible to surface inflow contamination, (2) calf feeder pens or unused animal pens, or (3) septic systems. The lagoon sample also plotted in the animal waste zone $(+18 \%$ ) .

All the monitoring sites (except well 7, downgradient of the lagoon) had nitrate greater than $10 \mathrm{mg} / \mathrm{L}$ and $\delta^{15} \mathrm{~N}$ values between +3 to $+8 \%$, indicating a probable fertilizer source for the nitrogen (Figure 8). There was seasonal variation to the $\delta^{15} \mathrm{~N}$ and nitrate values. Nitrate values were slightly lower in December than in March (except for M8), perhaps related to mineralization or denitrification processes. 


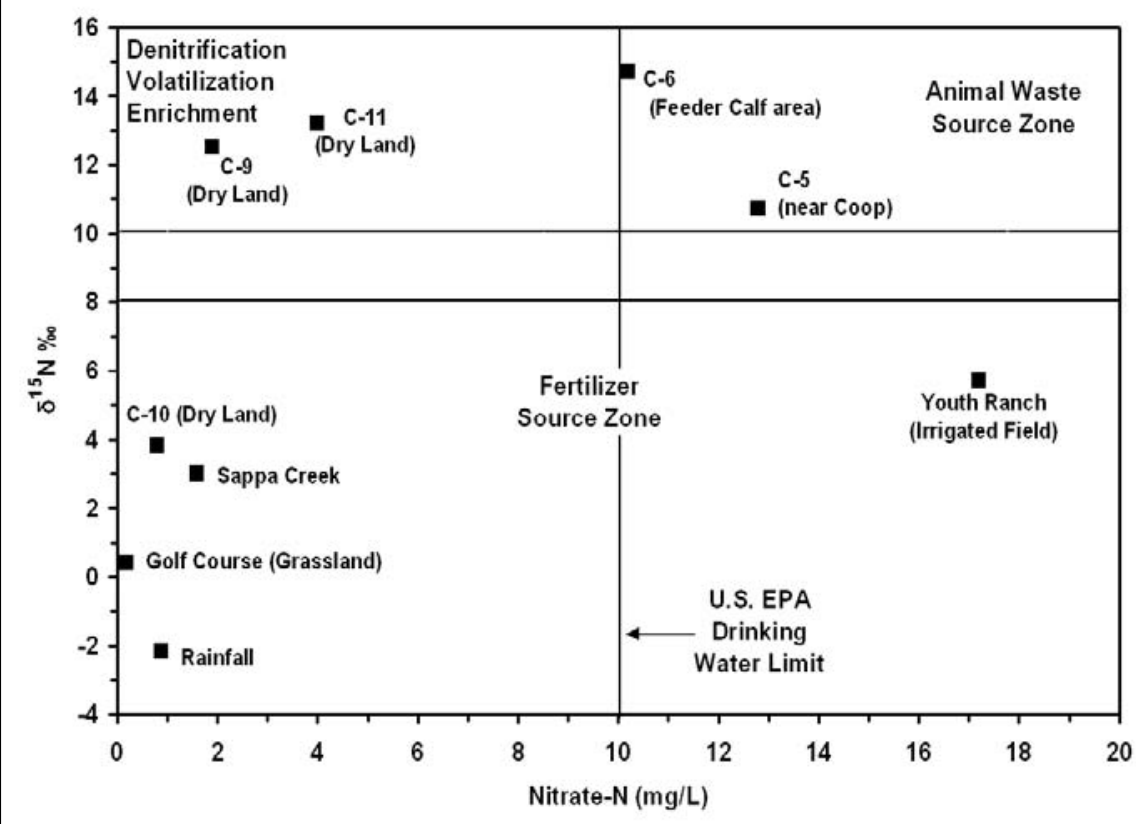

Figure 9. Nitrate and $\delta^{15} \mathrm{~N}$ values for samples from Oberlin, Kansas. The fertilizer-source zone can be from +0 to $+8 \%$ o. The animal waste zone is generally greater than $+10 \%$ o with nitrate above $10 \mathrm{mg} / \mathrm{L}$. The denitrification enrichment zone is frequently above $+10 \%$ o with nitrate values below 1 $\mathrm{mg} / \mathrm{L}$. Very low $\delta^{15} \mathrm{~N}$ values (golf course well) may be related to chemical oxidation of ammonium from clays with no resulting enrichment of ${ }^{15} \mathrm{~N}$ or denitrification enrichment of precipitation.

The samples collected in March 2000 had $\delta^{15} \mathrm{~N}$ values of +0.8 to $+1.2 \%$, whereas the 1999 samples (collected in December) had values in the +5 to $+9 \%$, suggesting that processes such as volatilization or denitrification affected the concentration and isotopic signature as groundwater moved from areas with fertilizer sources into the area influenced by the lagoon (Figures 4 and 8). The irrigation well to the east was sampled in July 2000. The $\delta^{15} \mathrm{~N}$ for this sample was $+5.8 \%$, within the fertilizer range.

The fact that the regional water quality of high nitrate (mean $18 \mathrm{mg} / \mathrm{L}$ ) and low $\delta^{15} \mathrm{~N}$ values (mean 3.8\%o) was transformed into low nitrate $(4.6 \mathrm{mg} / \mathrm{L})$ and an enriched $\delta^{15} \mathrm{~N}$ value $(+20 \%$ ) observed at well M7 strongly suggests that denitrification enrichment of the regional groundwater resulted in the decreased nitrate concentration and enriched $\delta^{15} \mathrm{~N}$ value at well M7.

\section{Nitrogen-15 Values from Oberlin Samples}

Figure 9 shows nitrate and $\delta^{15} \mathrm{~N}$ values along with zones indicating different probable sources and enrichment processes (Table 2). In this study, the sampled values were impacted by a 
variety of sources as is shown in Figure 9. The discussion below is based on one round of sampling in the area.

Based on the land use in the area near each well the overall nitrogen source for most of the samples is fertilizer. However, different processes have affected the $\delta^{15} \mathrm{~N}$ signatures for each sampling site. The Youth Ranch well (Figure 6) is impacted by irrigation and may retain the fertilizer signature because of permeable soils and a source of reliable recharge from irrigation water that pushes the nitrate through the soil profile relatively quickly.

Two of the dry land sites (wells C-9, and C-11) have enriched $\delta^{15} \mathrm{~N}$ values that may be related to long travel times. Long travel times could permit volatilization reactions to occur near observed caliche zones found in all the collected soil cores, thus resulting in low nitrate and enriched $\delta^{15} \mathrm{~N}$ values. It is also possible that denitrification reactions are also contributing to the enriched $\delta^{15} \mathrm{~N}$ values.

Some mixing of water between municipal wells and irrigation wells in the area could be happening. Wells C-10 and C-11 are used most consistently so long-term pumping may result in an increased area of influence from the well that might intersect the area from an irrigated field and pull nitrate to the well.

Well \#11 is next to a field that was used for alfalfa in the past. Decay of legume nodules over time results in a release of nitrate (R. Raymond, KSU, personal communication, 1999). Slow movement through the unsaturated zone and possible volatilization or denitrification reactions could explain the low nitrate but enriched $\delta^{15} \mathrm{~N}$.

Wells C-5 and C-6 are most impacted by probable point sources. The location of well C-5 near the local farm cooperative and the lack of use of this well suggest that past fertilizer spills provided the source of nitrate and denitrification, or volatilization reactions with the caliche zones are responsible for the enrichment. No source of animal waste was found near this well. Well C-6 is located in a calf feeder area. Because of the enriched $\delta^{15} \mathrm{~N}$ value, the high nitrate, and lack of use of the well, it is likely that the animal waste with possible volatilization enrichment in the soil profile has resulted in the enriched $\delta^{15} \mathrm{~N}$ value. 
The golf course well has the lowest nitrate and $\delta^{15} \mathrm{~N}$ values. The location of the well is in a non-irrigated area with native grass cover sited in silt loam soil near an abandoned oxbow portion of the creek. This site had reducing water chemistry as suggested by measurable iron and manganese (Table 2). The low nitrate value may be due to a slow release of ammonium-N from mineralized organic matter. The low $\delta^{15} \mathrm{~N}$ value may be due to chemical oxidation of this ammonium in a reducing environment (R. Spalding, UNL, unpublished data, 1995). This would result in low nitrate and low $\delta^{15} \mathrm{~N}$ values. The $\delta^{15} \mathrm{~N}$ and low nitrate- $\mathrm{N}$ value for a rainfall sample collected in Kansas suggests the possibility of denitrification enrichment of rainfall is another possible factor (Schulmeister, 1994).

The Oberlin, Kansas, site illustrates some of the difficulties in using ${ }^{15} \mathrm{~N}$ natural abundances to determine sources for the nitrate. Site-soil stratigraphy adds a level of complication in that volatilization and/or denitrification enrichment can occur because of long travel times in the unsaturated zone, and also the presence of caliche layers can permit chemical changes in the water and result in changes in the nitrogen-15 signature. A mixture of possible point and non-point sources also complicates the picture. The area around each well needed to be evaluated in a fairly detailed manner to try to determine possible sources for contamination. To truly understand the area, pumping tests should be done to try to determine if well interference and possible mixing of municipal and irrigation water is occurring. Although the general source appears to be fertilizer, several more rounds of sampling with nitrogen-15 analyses would probably result in a clearer picture of the overall source(s) of the nitrate in this area.

\section{CONCLUSIONS}

Identification of sources of nitrate in groundwater is often possible using the nitrogen-15 natural abundance method. However, biological and chemical processes can alter the $\delta^{15} \mathrm{~N}$ signature resulting in erroneous source assignment. Other information, such as complete water-chemical analyses, dissolved oxygen, $\mathrm{pH}$, other isotopic analyses, soil cores at the sites of interest, site evaluation around each sampling point, land use around each well (both past and present), and information on depth to groundwater and flow direction is needed to support the ${ }^{15} \mathrm{~N}$ data. 
The two case studies in Kansas showed potential benefits and problems of using the nitrogen-15 natural abundances to assess groundwater contamination. The Reno County study illustrated that the method may work well in areas with permeable soils, a shallow groundwater table, and water chemistry that has low anion concentrations (chloride, sulfate, bicarbonate) relative to the area of contamination. Use of alternative tracers such as chloride or other isotopes helps to support the nitrate-source identification from the nitrogen-15 data.

The study in Oberlin, Kansas, illustrated some of the potential problems in using the nitrogen-15 natural abundance method. The soil was a silty, clay loam with low permeability and observed caliche zones. Low precipitation, a relatively thick unsaturated zone, multiple sources near sampled wells, and enriched anion concentrations due to evapoconcentration of solutes further complicated the source identification. Because of the long travel times and the presence of potentially reactive caliche zones, it was difficult to determine if volatilization or denitrification caused the enriched $\delta^{15} \mathrm{~N}$ signatures. Site examination, determination of the historical and recent land use, and obtaining the record of well use in the city assisted in assigning the most probable sources for the observed nitrate.

In summary, use of nitrogen-15 natural abundances is a powerful tool for source identification of nitrate in groundwater when it is used in conjunction with other chemical and site-evaluation information. Used only by itself, the method may not provide an accurate identification of a nitrogen source to groundwater. Other factors such as seasonal variation because of land-use practices (such as application of fertilizer in the spring) or irrigation effects (such as evapoconcentration) need to be considered and evaluated in order to maximize the accuracy of the method.

\section{ACKNOWLEDGMENT}

The City of Oberlin, Kansas, Groundwater Management District \#2, and the Bureau of Confined Animal Waste Operations at the Kansas Department of Health and Environment partly funded the research projects discussed in this paper. The paper has not been subjected to the agencies' or city's review and therefore may not necessarily reflect the views of the agencies, and no official endorsement should be inferred. 


\section{REFERENCES}

Bayne, C. K., 1956, Geology and groundwater resources of Reno County, Kansas: Kansas Geological Survey, Bulletin 120,130 p.

Columbia Encyclopedia, 2003, http://www.encyclopedia.com/html/H/Haberpro.asp, 6th edition.

Dealey, M. T., 1995, Investigation of nitrate-nitrogen concentrations in the Equus Beds aquifer, southeast Reno County, Kansas: Equus Beds Groundwater Management District No. 2 , Water Quality Investigation 95-01, 57 p.

Drever, J. L., 1982, The geochemistry of natural waters: $1^{\text {st }}$ edition, Prentice-Hall, N.J., 388 p.

Gormly, J. R., and Spalding, R. F., 1979, Sources and concentrations of nitrate-nitrogen in groundwater of the Central Platte region, Nebraska: Ground Water, v. 3, pp. 291-301.

Ham, J. M., Reddi, L. N., and Rice, C. W., 2000, Animal waste lagoon water quality study: Kansas Water Office, Topeka, KS, Research Report 99-123, 138 p.

Hamilton, V. L., Angel, R. C., and Tricks, B. D., 1989, Soil survey of Decatur County, Kansas: USDA Soil Conservation Service (now NRCS), 75 p.

Hathaway, L. R., 1990, KGS nitrate-UV method for the Technicon Auto Analyzer II system: Kansas Geol. Survey Open-File Rept. 90-49, 4 p.

Hathaway, L. R., Waugh, T. C., Galle, O. K., and Dickey, H. P., 1981, Chemical quality of irrigation waters in the Equus Beds area, south-central Kansas: Kansas Geol. Survey Chem. Qual. Series 10, 45 p.

Heaton, T. H. E., 1986, Isotopic studies of nitrogen pollution in the hydrosphere and atmosphere: A review: Chemical Geology, v. 59, pp. 87-102.

Hem, J. D., 1985, Study and interpretation of the chemical characteristics of natural water: U. S. Geological Survey, Water-Supply Paper 2254, 263 p.

Herbel, M. J., and Spalding, R. F., 1993, Vadose zone fertilizer-derived nitrate and $\ddot{a}^{15} \mathrm{~N}$ extracts: Ground Water, v. 31, no. 3, pp. 376-382.

Hoefs, J., 2001, Stable isotope geochemistry, 4th ed.: Springer, 201 p.

Kansas Department of Agriculture, 2002, homepage: http://www.accesskansas.org/kda/ (verified September 2002).

Kansas Department of Health and Environment (KDHE), 1996, The evaluation of nitrate contamination in the Sand Springs study area: KDHE Bureau of Remediation, $123 \mathrm{p}$.

Kansas Geological Survey, 2002, homepage: http://www.kgs.ukans.edu/ (verified September 2002).

Kendall, C., 1998, Tracing nitrogen sources and cycling in catchments, In: C. Kendall and J. J. McDonnell (Eds.), Isotope Tracers in Catchment Hydrology, Elsevier, NY, pp. 519-576. 
Kohl, D. H., Shearer, G. B., and Commoner, B., 1971, Fertilizer nitrogen contribution to nitrate in surface water in a corn belt watershed: Science, v. 174, pp. 1331-1334.

Korom, S. F., 1992, Natural denitrification in the saturated zone: A review: Water Resources Research, v. 28, pp. 1657-1668.

Kreitler, C. W., 1975, Determining the source of nitrate in groundwater by nitrogen isotope studies: Rept. of Invest. \#83, Univ. of Texas at Austin, Austin, TX, Bureau of Econ. Geol., 57 p.

Kreitler, C. W., 1979, Nitrogen-isotope ratio studies of soils and groundwater nitrate from alluvial fan aquifers in Texas: Jour of Hydrol., v. 42, pp. 147-170.

Kreitler, C. W., and Jones, D. C., 1975, Natural soil nitrate: The cause of the nitrate contamination of groundwater in Runnels County, Texas: Groundwater, v. 13, p. 53-61.

Macko, S.A., and Ostrom, N.E., 1994, Pollution studies using stable isotopes. Stable Isotopes, In: K. Lajtha and R. Michener (eds.), Ecology, Blackwell Scientific Pub., Oxford, UK, pp. 45-62.

Mariotti, A., Landreau, A., and Simon, B., 1988, ${ }^{15} \mathrm{~N}$ isotope biogeochemistry and natural denitrification process in groundwater: Application to the chalk aquifer of northern France: Geochem. et Cosmochim. Acta, v. 52, pp. 1869-1878.

Mitchell, R. J., Babcock, R. S., Gelinas, S., Nanus, L., and Stasney, D. E., 2003, Nitrate distributions and source identification in the Abbotsford-Sumas Aquifer, northwestern Washington state: J. Environ. Qual. v. 32, pp. 789-800.

Mueller, D. K., and Helsel, D. R., 1996, Nutrients in the nation's waters - too much of a good thing?: U.S. Geological Survey Circular 1136, 24 p.

Schulmeister, M. K., 1994, Spatial and temporal variations in del-15N of $\mathrm{NO}_{3}-\mathrm{N}$ - preliminary evaluation of an alluvial aquifer in Kansas, USA: Geological Society of America 1994 Annual Meeting Abstracts with Programs, p. A-323.

Shearer, G. B., Kohl, D. H., and Chien, S. H., 1978, The nitrogen-15 abundance in a wide variety of soils: Soil Sci. Soc. of Am. Jour., v. 42, pp. 899-902.

Townsend, M. A., 2001, Use of natural abundance nitrogen-15 isotope method to identify sources of nitrate in groundwater near Oberlin, Kansas: Kansas Geological Survey, Open file Rept. 2001-50, $20 \mathrm{p}$

Townsend, M. A., Macko, S. A., and Young, D. P., 2001, Distribution and sources of nitratenitrogen in Kansas groundwater, In: Optimizing Nitrogen Management in Food and Energy Production and Environmental Protection: Proceedings of the $2^{\text {nd }}$ International Nitrogen Conference on Science and Policy, The Scientific World 1 (S2), pp. 216-222.

Townsend, M. A. and Young, D. P., 2000, Assessment of nitrate-nitrogen distribution in Kansas groundwater, 1990-1998: Natural Res. Research, v. 9, no. 2, pp. 125-134.

Townsend, M. A., 2000, Reno County Swine Facility Report: KGS Open File Report 2000-41, 26 p.

Townsend, M. A., Macko, S., Young, D. P., and Sleezer, R. O., 1994, Natural ${ }^{15} \mathrm{~N}$ isotopic signatures in groundwater: A cautionary note on interpretation: Kansas Geological Survey, Openfile Report 94-29, 24 p. 
U.S. Department of Agriculture (Natural Resources Conservation Service), 2002, Soil Database web site http://www.statlab.iastate.edu/soils/sc/ (verified August 2002).

U. S. Environmental Protection Agency, 2002, National Primary Drinking Water Standards EPA 816-F-02-013: http://www.epa.gov/safewater/mcl.html\#inorganic (verified August 2003).

U. S. Geological Survey, 2002, National Water Information System (NWISWeb) http:// waterdata.usgs.gov/ks/nwis/(verified September, 2003).

Whittemore, D. O., 1995, Geochemical differentiation of oil and gas brine from other saltwater sources contaminating water resources: Case studies from Kansas and Oklahoma: Environmental Geosciences, vol. 2, no.1, pp. 15-31.

Wilson, B. B., 1998, Water Information Management and Analysis System (WIMAS), ver.4, for ArcView User's Manual: Kansas Dept. of Agriculture, Div. of Water Resources, 35 p.

Young, D. P., 1992, Nitrate contamination of groundwater in northern Stafford County, Kansas: M. S. thesis, Univ. KS, Dept. Civil Engineering, 94 p.

Original Manuscript Received: October 3, 2002

Revised Manuscript Received: November 18, 2003 